\title{
Chrysoviruses Inhabited Symbiotic Fungi of Lichens
}

\author{
Karel Petrzik ${ }^{1, *(\mathbb{D})}$, Igor Koloniuk $\left.{ }^{1} \mathbb{(}\right)$, Hana Sehadová ${ }^{2,3}$ [D and Tatiana Sarkisova ${ }^{1}$ \\ 1 Department of Plant Virology, Institute of Plant Molecular Biology, Biology Centre, Czech Academy of \\ Sciences, Branišovská 31, 37005 České Budějovice, Czech Republic; koloniuk@umbr.cas.cz (I.K.); \\ sarkisova@umbr.cas.cz (T.S.) \\ 2 Institute of Entomology, Biology Centre, Czech Academy of Sciences, Branišovská 31, 37005 České \\ Budějovice, Czech Republic; sehadova@entu.cas.cz \\ 3 Faculty of Science, University of South Bohemia, Branišovská 31, 37005 České Budějovice, Czech Republic \\ * Correspondence: petrzik@umbr.cas.cz; Tel.: +420-387-775-549
}

Received: 5 November 2019; Accepted: 30 November 2019; Published: 3 December 2019

\begin{abstract}
A lichen body is formed most often from green alga cells trapped in a net of ascomycetous fungi and accompanied by endolichenic or parasitic fungi, other algae, and symbiotic or free-living bacteria. The lichen's microcosmos is inhabited by mites, insects, and other animals for which the lichen is a source of food or a place to live. Novel, four-segmented dsRNA viruses were detected in saxicolous Chrysothrix chlorina and Lepraria incana lichens. Comparison of encoded genome proteins revealed classification of the viruses to the genus Alphachrysovirus and a relationship to chrysoviruses from filamentous ascomycetous fungi. We propose the names Chrysothrix chrysovirus 1 (CcCV1) and Lepraria chrysovirus 1 (LiCV1) as acronyms for these viruses. Surprisingly, observation of Chrysothrix chlorina hybridization with fluorescent-labelled virus probe by confocal microscope revealed that the CcCV1 virus is not present in the lichen body-forming fungus but in accompanying endolichenic Penicillium citreosulfuratum fungus. These are the first descriptions of mycoviruses from a lichen environment.
\end{abstract}

Keywords: saxicolous lichen; ascomycete; chrysovirus; complete genome; confocal microscopy

\section{Introduction}

Fungi are ancient organisms whose major lineages originated in the Precambrian [1]. They are essential constituents of modern terrestrial and aquatic ecosystems and partners with plants and other organisms. Lichens also comprise ancient symbiotic associations, most often between ascomycetous fungi (rarely basidiomycetous) from classes Lecanoromycetes or Lichinomycetes and green algae or cyanobacteria [2]. This symbiosis is one of the most successful life forms in nature and allows the partners to expand into habitats where separately they would be rare or nonexistent (including extremely cold, hot, dry, or toxic environments). In addition to the two main partners, there are other lichenicolous fungi, endolichenic fungi, and lichen-associated bacteria within lichen thalli composing specific complex microbial microcosms [3-5]. Bacteria that live externally from the fungal cells or as endosymbionts contribute to a complex symbiotic network with multiple functions. They could complement the nitrogen budget and/or provide defense against lichen pathogens and feeders. They have lytic activities; produce bioactive substances, hormones, and antibiotics; metabolize decaying lichen material; and are present in the lichen-substrate interface [4]. On the other hand, it seems that growth of the bacteria is under control of the lichens. Lichens are only rarely eradicated by pathogens. It is assumed that growth of the parasites requires tolerance to lichen compounds or prior breakdown of the lichen's chemical defense $[2,6]$. Some exceptions do exist, as in the case of various Fusarium species, and these parasites attack a variety of lichens and are tolerant of many lichen defense compounds [7]. Moreover, several species of Caloplaca are known to have parasitic phases in their life 
cycles during which they take over other crustose lichens [8,9]. A killer is the basidiomycete Athelia arachnoidea, which has been shown to attack and destroy Lecanora conizaeoides lichen [10]. Neither can a presence of specific viruses in lichens be excluded, because a wide range of mycoviruses and viruses specific to green algae and cyanobacteria are known to infect free-living ascomycetous fungi, algae, and cyanobacteria [11-13]. In addition, with the advent of next-generation sequencing technology, the strict borders previously assumed to exist between the host preferences of plant viruses, mycoviruses, insect viruses, human viruses, and the like have become less strict as interkingdom infections have been described. Cytorhabdovirus sequences similar to plant cytorhabdoviruses have been amplified from Cladonia arbuscula lichen, as has been an Apple mosaic virus (a plant ilarvirus) from different Usnea sp., Xanthoria parietina, and Cladonia arbuscula samples [14]. Conversely, some viruses similar to mycoviruses have been found also in plants [15,16], and chlorovirus ATCV-1 infecting eukaryotic green algae has been found to be a part of the human virome [17].

The lichen genus Chrysothrix Mont. is characterized by the yellow, lemon to bright yellow, or golden yellow thallus containing pulvinic acid derivatives that give the lichens their characteristic color. Chrysothrix chlorina (Ach.) J. R. Laundon (syn. Crocynia chlorina, Lepraria chlorina, gold dust lichens, sulfur dust lichens) is a morphologically simple lichen-forming ascomycetous fungus in the family Chrysothricaceae, class Lecanoromycetes. The lichen is a widely distributed saxicolous (growing on rocks) and crustose (strongly adhered to the substrate) organism from the lowlands to the mountains in the temperate and arctic zones of both the Northern and Southern hemispheres. It has a thallus without cortex and reproduces asexually. The lichen never has been found with ascomata or conidiomata [18]. There is speculation that the pulvinic acid derivatives protect the lichen from some herbivores and have an antibacterial activity against gram-positive bacteria [19]. Vulpinic acid from this lichen has emerged recently as a potential drug candidate in the therapy of atherosclerosis [20]. Lepraria incana (L.) Ach. (family Stereocaulaceae, class Lecanoromycetes) is a morphologically simple, granular, grayish or greenish lichen growing all over the world on bark, acidic rock, wood and soil in shady places [21]. This lichen is sterile and never develops fruiting bodies (ascomata or conidiomata).

Mycoviruses are widely distributed cohabitants in fungi. Recently, they have been found in Basidiomycota as well as in Ascomycota. Furthermore, Plasmodiophorids and Chytrids (Chytridiomycota) are known vectors of some plant viruses belonging to the Bymo-, Beny-, Furo-, Peclu-, and Pomovirus genera [22]. Only a small number of known mycoviruses have deleterious effects on their hosts. Most infections are asymptomatic and do not affect host vigor, growth rate, or multiplication. The genomes of known mycoviruses consist of ssDNA, ssRNA, and, more predominantly, dsRNA. The low-cost and simple protocol of Morris and Dodds [23] is widely used for extraction of dsRNA, which is indicative for a presence of replicative ssRNA viruses as well as for dsRNA viruses in hosts. This approach has allowed us to screen different lichen samples for viral nucleic acids. In this paper, we describe for the first time two novel chrysoviruses found in simple lichens and present their localization in the lichen body.

\section{Materials and Methods}

\subsection{Lichen Samples}

Chrysothrix chlorina sample ZSH was scraped from granite rocks in the Vltava River valley (49.0737153N, 14.4529036E) in the České Budějovice countryside (Czech Republic). The Lepraria incana lichen sample DK10 was from growths in crevices of shadowed, wet rock at a location about $20 \mathrm{~km}$ upriver from the first (48.8904328N, 14.3561922E). Material of non-lichen origin was manually removed before further manipulation. Samples were washed in distilled water, surface-sterilized in 5\% sodium hypochlorite for $15 \mathrm{~min}$, and washed twice in water. Due to a limited amount of the DK10 sample, only partial sequencing was performed with this lichen. All other experiments were performed with the ZSH sample. 


\subsection{Double-Stranded RNA Extraction and Virus Sequencing}

Double-stranded RNA was extracted from about $0.1 \mathrm{~g}$ of wet lichen thalli by the CF-11 cellulose chromatography method, as described previously [23]. Extracted nucleic acid was diluted in $50 \mu \mathrm{l}$ of water. Co-purified DNA and ssRNA were then removed by DNase I and S1 nuclease treatment for $15 \mathrm{~min}$ each. After phenol/chloroform extraction and ethanol precipitation, the dsRNA was diluted in $20 \mu \mathrm{l}$ of TE buffer (10 mM Tris-HCl, pH 8.0, 5 mM EDTA) and separated on agarose gel. Total lichen RNA was isolated using a NucleoSpin RNA Plant Kit (Macherey Nagel, Düren, Germany) according to the manufacturer's instructions.

Complementary DNA (cDNA) was prepared with Superscript III reverse transcriptase (Invitrogen, Carlsbad, CA, USA) and tagged random primer 5'-CGATCGATCATGATGCAATGCNNNNNN-3'. The random cDNA products were then amplified using a single specific primer, 5'-CGATCGATCATGATGCAATGC-3' [24]. The pool of polymerase chain reaction (PCR) products was ligated to pGEM-T Easy vector (Promega, Madison, WI, USA) and used for transformation of NEB 10-beta competent Escherichia coli cells. The $5^{\prime}$ and $3^{\prime}$ terminal sequences of each viral genome segment were obtained using $5^{\prime} / 3^{\prime}$ rapid amplification of cDNA ends (RACE) protocol with specific primers (see Table S1). The $18 \mathrm{~S}$ rDNA sequence of lichen fungus was amplified with ITS1 and ITS4 primers [25], cloned, and then sequenced.

\subsection{Lichen Symbionts Separation}

Lichen alga isolation was prepared according to Gasulla et al. [26] from $20 \mathrm{mg}$ of lichen thalli by one-step centrifugation through Percoll ${ }^{\mathrm{TM}}$. Briefly, about $20 \mathrm{mg}$ of lichen thalli was surface-sterilized in $2 \%$ sodium hypochlorite, washed with sterile water, then homogenized in $0.3 \mathrm{M}$ sorbitol in $50 \mathrm{mM}$ HEPES, pH 7.5. After filtration, the filtrate was centrifuged at $500 \times g$ for $5 \mathrm{~min}$. The pellet was resuspended in sorbitol buffer and loaded onto $80 \%$ Percoll $^{\mathrm{TM}}$ in sorbitol buffer. After centrifugation at $10,000 \times g$ for $10 \mathrm{~min}$, a green layer near the top was collected, resuspended in the buffer, and a second round of centrifugation was performed on $80 \%$ Percoll $^{\mathrm{TM}}$. Collected green layer was diluted in sterile water and centrifuged at $1000 \times g$ for $10 \mathrm{~min}$. The pellet was then resuspended in $2 \mathrm{~mL}$ of sterile water, sonicated for $30 \mathrm{~s}$, then centrifuged at $500 \times g$ for $5 \mathrm{~min}$. This treatment was repeated 5 times.

Total nucleic acid was prepared from the final pellet containing the algal cells and, after the first centrifugation, from the sediment containing both algal and fungal cells using a NucleoSpin RNA Plant Kit (Macherey Nagel) according to the manufacturer's instructions.

Multiple sequence alignments were carried out using the CLUSTALx [27] and MEGA v.7 programs [28]. Maximum likelihood analysis was used to infer virus phylogeny with 1000 bootstrap replicates.

Relative concentration of the virus in lichen thalli was estimated from quantitative real-time PCR (q-RT-PCR) performed in the CFX96 Real-Time System (Bio-Rad Laboratories, Hercules, CA, USA) with primers 1901 and 1902 (see Table S1) amplifying the GAPDH housekeeping gene [29] and 846 and 847 primers specific for the RNA4 segment of the virus.

\subsection{In situ Hybridization}

For in situ hybridization, Cy3-labeled probes MY1574 5'-TCCTCGTTGAAGAGC-3' specific for a wide range of Eumycota [30] and 859 probe $5^{\prime}$-GGGCAAATAGAGAGAAGG-3' for the dsRNA3 segment of CcCV1 were synthesized (Sigma-Aldrich, St. Louis, MO, USA). Standard techniques were used for thalli tissue paraformaldehyde fixation, dehydration, embedding in Paraplast ${ }^{\circledR}$, sectioning to $6 \mu \mathrm{m}$, deparaffinization, and rehydration. Penicillium citreosulfuratum samples for hybridization were taken from aerial hyphae of the fungus cultivated 10 days on potato dextrose agar (PDA) plates. The samples were then treated with chitinase for $15 \mathrm{~min}$ in $1 \times$ phosphate-buffered saline buffer with $1 \%$ sodium dodecyl sulfate (SDS), $\mathrm{pH} 5.5$, at $30^{\circ} \mathrm{C}$ and then rinsed with distilled water. Prehybridization was performed in the hybridization buffer $(0.9 \mathrm{M} \mathrm{NaCl}, 20 \mathrm{mM}$ Tris- $\mathrm{HCl}$ ( $\mathrm{pH} 7.2), 0.03 \%$ SDS and 
$20 \%$ formamide) at $46^{\circ} \mathrm{C}$ for $3 \mathrm{~h}$. The samples were then hybridized with the probes in concentration $5 \mathrm{ng}$ per $\mu \mathrm{l}$ of hybridization buffer at $46^{\circ} \mathrm{C}$ overnight. They were then rinsed with $20 \mathrm{mM}$ Tris- $\mathrm{HCl}$ (pH 7.2), 0.01\% SDS, and $250 \mathrm{mM}, 88 \mathrm{mM}, 62 \mathrm{mM}$, and $31 \mathrm{mM} \mathrm{NaCl}$ buffer at $46^{\circ} \mathrm{C}$ for $20 \mathrm{~min}$ each. Some samples were stained with calcofluor white (Merck, Darmstadt, Germany) for 5 min. Stained sections were rinsed in distilled water, dehydrated, mounted in DPX mounting medium (Fluka, part of Fisher Scientific, Hampton, NH, USA), then viewed and imaged under a Fluoview FV3000 confocal laser scanning microscope (Olympus, Shinjuku, Tokyo, Japan).

\section{Results}

\subsection{Lichen Identification}

Based on morphological features, the lichen sample ZSH was identified as Chrysothrix chlorina. The sequence of the algal symbiont (MN396489) was 98\% identical to the GU017647 sequence of Asterochloris phycobiontica. Partial ribosomal sequence of the lichen fungus was amplified with ITS1 and ITS4 primers, sequenced, then compared in BLAST with the GenBank database. The lichen of the DK10 sample was identified as Lepraria incana. The $18 \mathrm{~S}$ rDNA sequence (MN393971) was 95\% identical with L. incana sequence AF517899 deposited in GenBank. The algal symbiont of this virus (MN396484) was 97\% identical to uncultured Trebouxia sp. sequence AY250848.

\section{2. dsRNA Presence}

In ZSH, a high molecular weight dsRNA band around $3.5 \mathrm{kbp}$ was visible after separation on agarose gel (Figure 1). After sequencing, four components were recognized in this material. In DK10, four bands within the range 2 to almost $4 \mathrm{kbp}$ were visible (Figure S3).
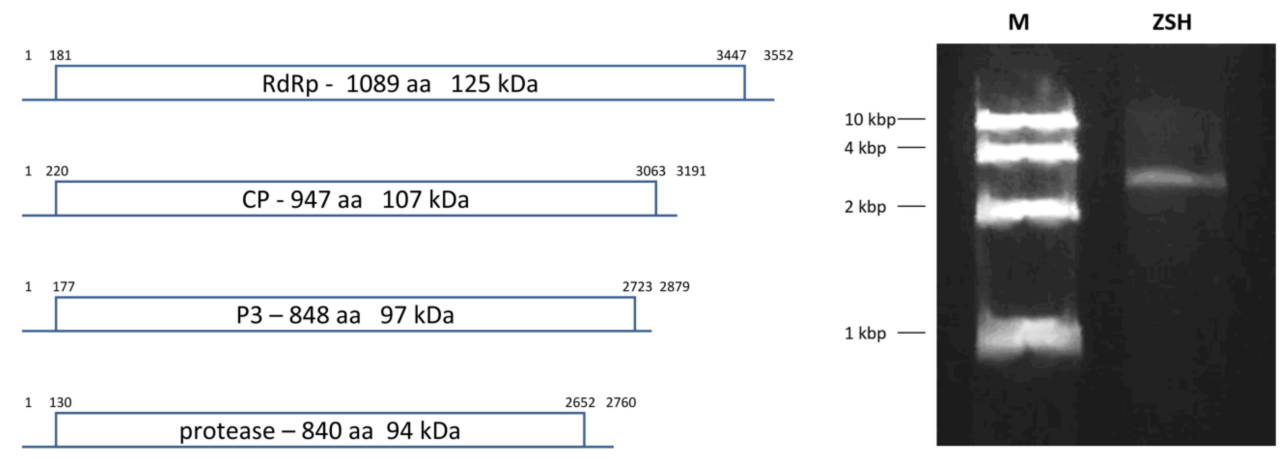

A

B

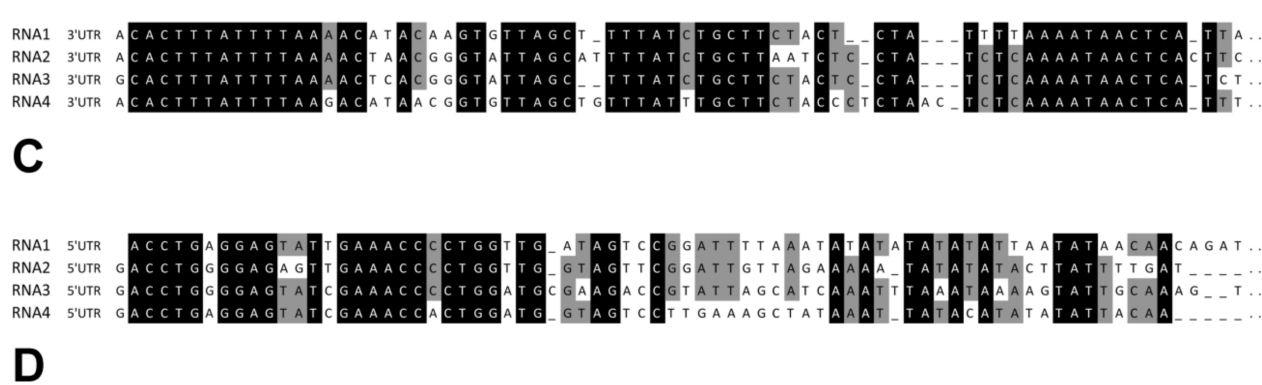

Figure 1. Genome characteristics of Chrysothrix chrysovirus 1 (CcCV1) from the ZSH sample. (A) Genome arrangement. (B) dsRNA isolated from ZSH lichen sample. M-DNA size standard of $10 \mathrm{kbp}, 4$ $\mathrm{kbp}, 2 \mathrm{kbp}$, and $1 \mathrm{kbp}$. (C) Alignment of 3'UTR (untranslated region) sequences of distinct segments of CcCV1. (D) Alignment of 5'UTR sequences of distinct segments of CCCV1. 


\subsection{Concentration of the Virus in Lichen}

We had expected the lichen-forming fungus to be the host of these extrachromosomal dsRNAs, because no high molecular weight dsRNA was visible after extraction from partially purified algal symbiont. Algal layer after the third round of sonication/centrifugation was used for RNA isolation and q-RT-PCR detection. Virus-specific detection primers were prepared according to the obtained sequences and RT-PCR detection was performed in parallel in algal symbiont as well as fungal symbiont. No signal increase was observed after 40 rounds of amplification.

Relative concentration of the virus in lichen thalli was estimated from total RNA isolations from three different samplings. In a single isolation, only the virus-specific signal in q-RT-PCR occurred 10 cycles after the GAPDH signal, while in the other two isolations the virus concentration was below the detection level. This means that the relative concentration of the virus in $\mathrm{ZSH}$ samples varies significantly and was as little as one-thousandth the concentration of GAPDH.

\subsection{Genome Description of the Viruses}

We determined the complete nucleotide sequence of all dsRNA segments in the ZSH sample. The 5' - and 3'-termini of the four dsRNAs share conserved sequences (Figure 1). The (CAA) $n$ repeat that works as the enhancer element in chrysoviruses was present 5 to 9 times in the $5^{\prime}$-untranslated regions (UTR) of distinct segments. Only for the DK10 isolate were $5^{\prime}$-terminal regions of dsRNA1 and dsRNA2 segments obtained. Both revealed significant nucleotide sequence identity in that region, and this supports the assumption that they belong to a single virus.

The dsRNA1 segment from the ZSH sample was $3552 \mathrm{nt}$ long and contained a single open reading frame (ORF) of 1089 amino acids (aa) with predicted molecular mass $125.5 \mathrm{kDa}$. The eight conserved RNA-dependent RNA polymerase motifs (RdRP_4) characteristic of RNA mycoviruses were localized in the central part of the protein (Figure 2). The polymerase of the ZSH isolate shows significant similarities to its counterpart in Penicillium roseopurpureum chrysovirus 1 (61\% identity, Figure 3). The dsRNA2 segment was $3191 \mathrm{nt}$ long and encoded a protein of 947 aa (predicted molecular mass $107 \mathrm{kDa}$ ) showing highest similarity to the capsid protein (CP) of Penicillium raistrickii chrysovirus $1(36 \%)$ (Figure 4$)$. The dsRNA3 segment was $2879 \mathrm{nt}$ long and encoded a single protein of 848 aa (predicted molecular mass $97 \mathrm{kDa}$ ). This protein is only distantly related to the corresponding protein of other chrysoviruses. The corresponding AfuCV protein was recognized as the most similar $(24.3 \%$ aa identity) (Figure S1). The dsRNA4 segment was $2776 \mathrm{nt}$ long and encoded a protein of 840 aa (predicted molecular mass $94 \mathrm{kDa}$ ). Presence of ubiquitin thioesterase domain $(\mathrm{E}=0.000011$ ) was predicted in the C-terminal part of the protein by HHpred [31]. A hypothetical protein of AfuCV was identified as the most similar, with $45 \%$ aa identity (Figure S2).

Partial sequences of dsRNA1, dsRNA2, and dsRNA4 segments of a chrysovirus were obtained from the DK10 sample. We did not obtain a sequence of the fourth segment visible on the gel. These sequences represent $84 \%, 78 \%$, and $72 \%$ of segments size for the most similar Colletotrichum gloeosporioides chrysovirus 1 (Figure S3) and reveal 51\%, 36\%, and 37\% identity with the corresponding proteins of $\mathrm{CgCV}$. All eight conserved RdRp motifs characteristic of dsRNA mycoviruses were detected on the in silico translated sequence of the dsRNA1 segment and shared high identity with related alphachrysoviruses (Figure 2). 


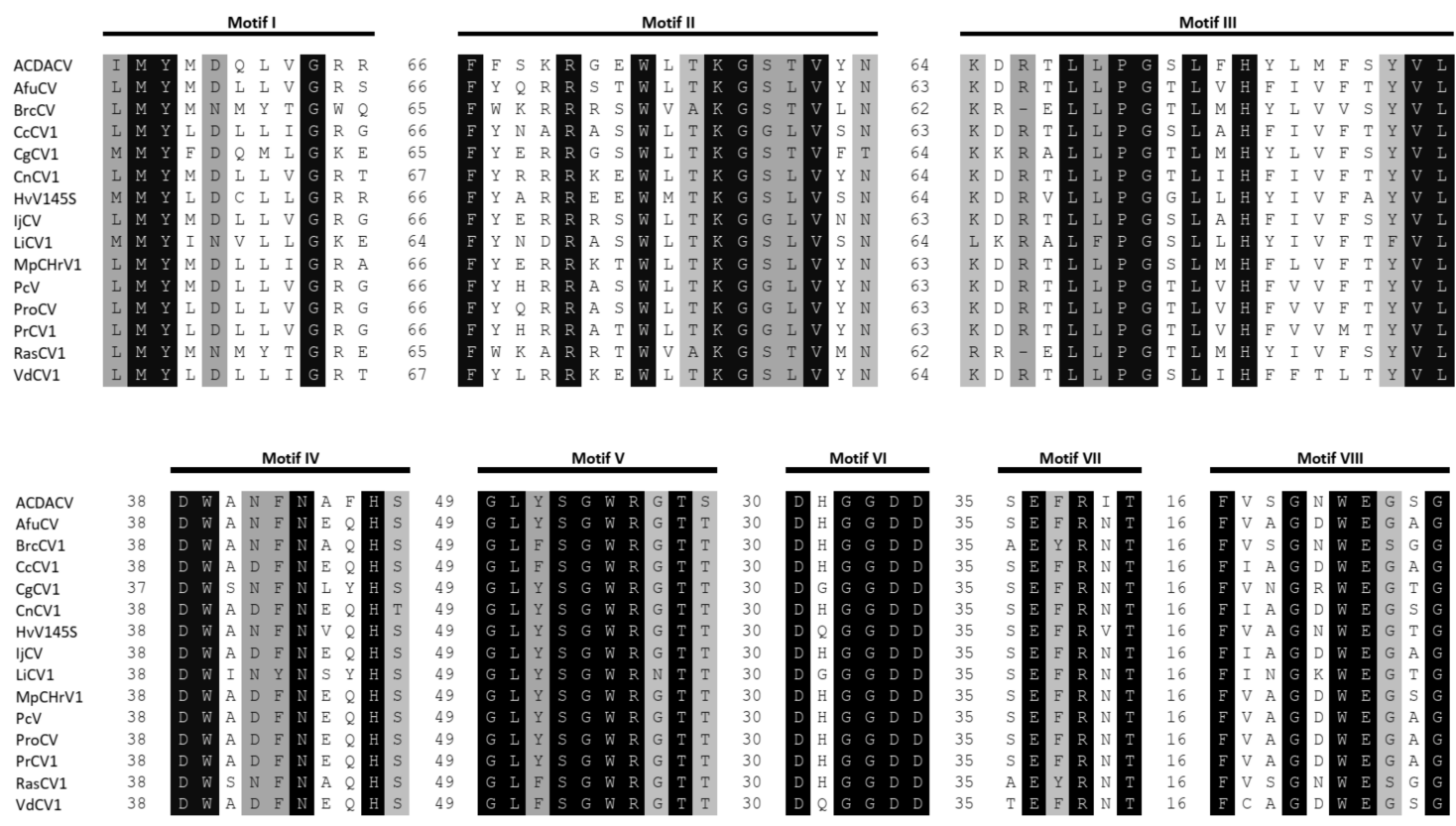

Figure 2. Alignment of amino acid sequences of the conserved I to VIII RdRp motifs of alphachrysoviruses. For virus acronyms, see Table S2.

\begin{tabular}{|c|c|c|c|c|c|c|c|c|c|c|c|c|c|c|c|}
\hline & 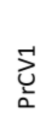 & 己̀ & 己̀ & $\underset{\frac{2}{2}}{\frac{3}{4}}$ & 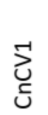 & ? & 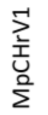 & $\underset{U}{J}$ & $\frac{3}{3}$ & 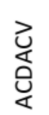 & 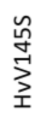 & $\sum_{\substack{0 \\
0}}^{F}$ & 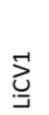 & 芯 & 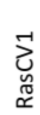 \\
\hline PrCV1 & & 88 & 86 & 71 & 59 & 59 & 53 & 48 & 45 & 35 & 35 & 34 & 34 & 33 & 35 \\
\hline PcV & 88 & & 84 & 69 & 58 & 59 & 53 & 48 & 45 & 34 & 35 & 34 & 35 & 34 & 34 \\
\hline ProCV & 86 & 84 & & 69 & 61 & 59 & 52 & 48 & 46 & 34 & 35 & 35 & 35 & 33 & 34 \\
\hline AfuCV & 71 & 69 & 69 & & 59 & 58 & 53 & 48 & 45 & 34 & 36 & 33 & 33 & 32 & 34 \\
\hline CnCV1 & 59 & 58 & 61 & 59 & & 58 & 52 & 49 & 46 & 35 & 36 & 33 & 37 & 34 & 34 \\
\hline IjCV & 59 & 59 & 59 & 58 & 58 & & 54 & 49 & 47 & 36 & 35 & 34 & 35 & 34 & 36 \\
\hline MpCHrV1 & 53 & 53 & 52 & 53 & 52 & 54 & & 50 & 49 & 36 & 38 & 34 & 34 & 33 & 34 \\
\hline CcCV1 & 48 & 48 & 48 & 48 & 49 & 49 & 50 & & 65 & 36 & 38 & 36 & 35 & 35 & 36 \\
\hline VdCV1 & 45 & 45 & 46 & 45 & 46 & 47 & 49 & 65 & & 34 & 37 & 33 & 34 & 35 & 35 \\
\hline ACDACV & 35 & 34 & 34 & 34 & 35 & 36 & 36 & 36 & 34 & & 42 & 36 & 37 & 33 & 33 \\
\hline HvV145S & 35 & 35 & 35 & 36 & 36 & 35 & 38 & 38 & 37 & 42 & & 38 & 40 & 34 & 35 \\
\hline CgCV1 & 34 & 34 & 35 & 33 & 33 & 34 & 34 & 36 & 33 & 36 & 38 & & 51 & 33 & 31 \\
\hline LiCV1 & 34 & 35 & 35 & 33 & 37 & 35 & 34 & 35 & 34 & 37 & 40 & 51 & & 33 & 33 \\
\hline $\mathrm{BrcCV} 1$ & 33 & 34 & 33 & 32 & 34 & 34 & 33 & 35 & 35 & 33 & 34 & 33 & 33 & & 61 \\
\hline RasCV1 & 35 & 34 & 34 & 34 & 34 & 36 & 34 & 36 & 35 & 33 & 35 & 31 & 33 & 61 & \\
\hline
\end{tabular}

Figure 3. Amino acid sequence identity and heat map of RdRp protein of alphachrysoviruses. A darker color indicates a higher sequence identity. 


\begin{tabular}{|c|c|c|c|c|c|c|c|c|}
\hline & ì & $\sum_{0}^{-1}$ & $\underset{⿱ 乛 龰 女}{\frac{3}{4}}$ & $\overbrace{\mathcal{U}}^{+}$ & $\sum_{0}^{5}$ & ?בֶ & $\begin{array}{l}\sum \\
\text { 논 } \\
\text { 을 }\end{array}$ & $\sum_{0}^{5}$ \\
\hline $\mathrm{PcV}$ & & 79 & 51 & 35 & 34 & 33 & 29 & 21 \\
\hline PrCV1 & 79 & & 50 & 35 & 34 & 34 & 29 & 20 \\
\hline AfuCV & 51 & 50 & & 36 & 35 & 35 & 29 & 22 \\
\hline $\mathrm{CcCV} 1$ & 35 & 35 & 36 & & 34 & 33 & 28 & 23 \\
\hline $\mathrm{BbCV} 1$ & 34 & 34 & 35 & 34 & & 68 & 31 & 23 \\
\hline IjCV & 33 & 34 & 35 & 33 & 68 & & 30 & 22 \\
\hline MpCHrV1 & 29 & 29 & 29 & 28 & 31 & 30 & & 23 \\
\hline VdCV1 & 21 & 20 & 22 & 23 & 22 & 22 & 23 & \\
\hline
\end{tabular}

Figure 4. Amino acid sequence identity and heat map of capsid protein of chrysoviruses. A darker color indicates a higher sequence identity.

\subsection{Taxonomic Relationship}

The taxonomic criteria for differentiating species within the family Chrysoviridae reflect host isolation, less than $70 \%$ aa sequence identity in the RdRp, size of segments, length of $5^{\prime}$-UTR, and serological relationships [32]. In the phylogenetic tree computed on RdRp aa sequences, the virus from the ZSH sample was placed close to Isaria javanica chrysovirus 1 (Figure 5). The virus from the DK10 sample was placed in a branch together with Colletotrichum gloeosporioides chrysovirus. Similar relationships were observed also on the phylogenetic tree computed from the $\mathrm{CP}$ aa sequences (Figure 6). Based on the RdRp aa sequence identities and with respect to the other taxonomic criteria for chrysoviruses, we concluded that the two viruses detected in the lichen samples represent novel species in the genus Alphachrysovirus. We propose for these viruses the names Chrysothrix chrysovirus 1 (CcCV1) and Lepraria chrysovirus 1 (LiCV1), reflecting the names of their host sources.

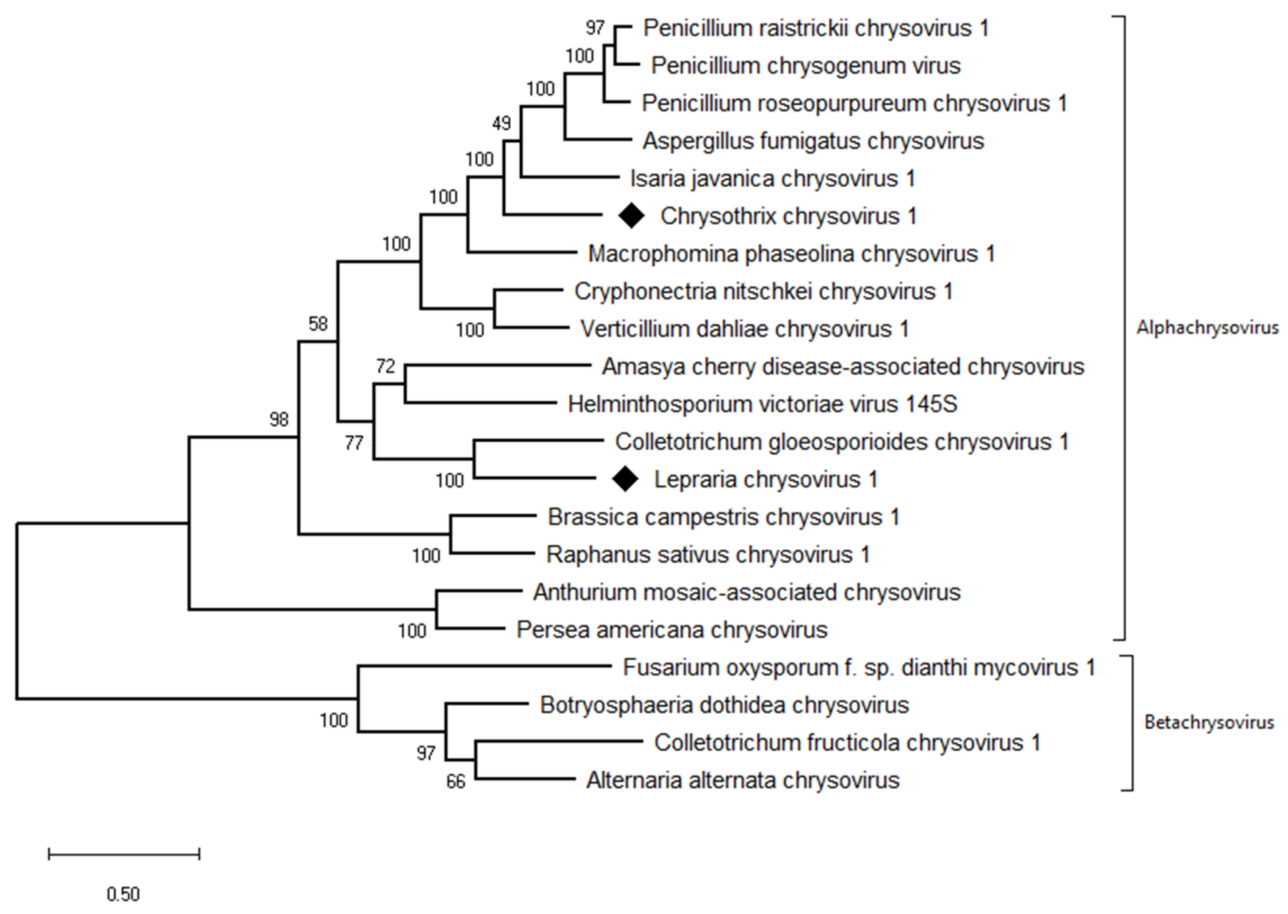

Figure 5. Phylogenetic maximum-likelihood tree computed on RdRp amino acid sequences of alphachrysoviruses and related betachrysoviruses. The values at the nodes are bootstrap values estimated by 1000 replicates. Diamonds highlight the viruses of this work. 


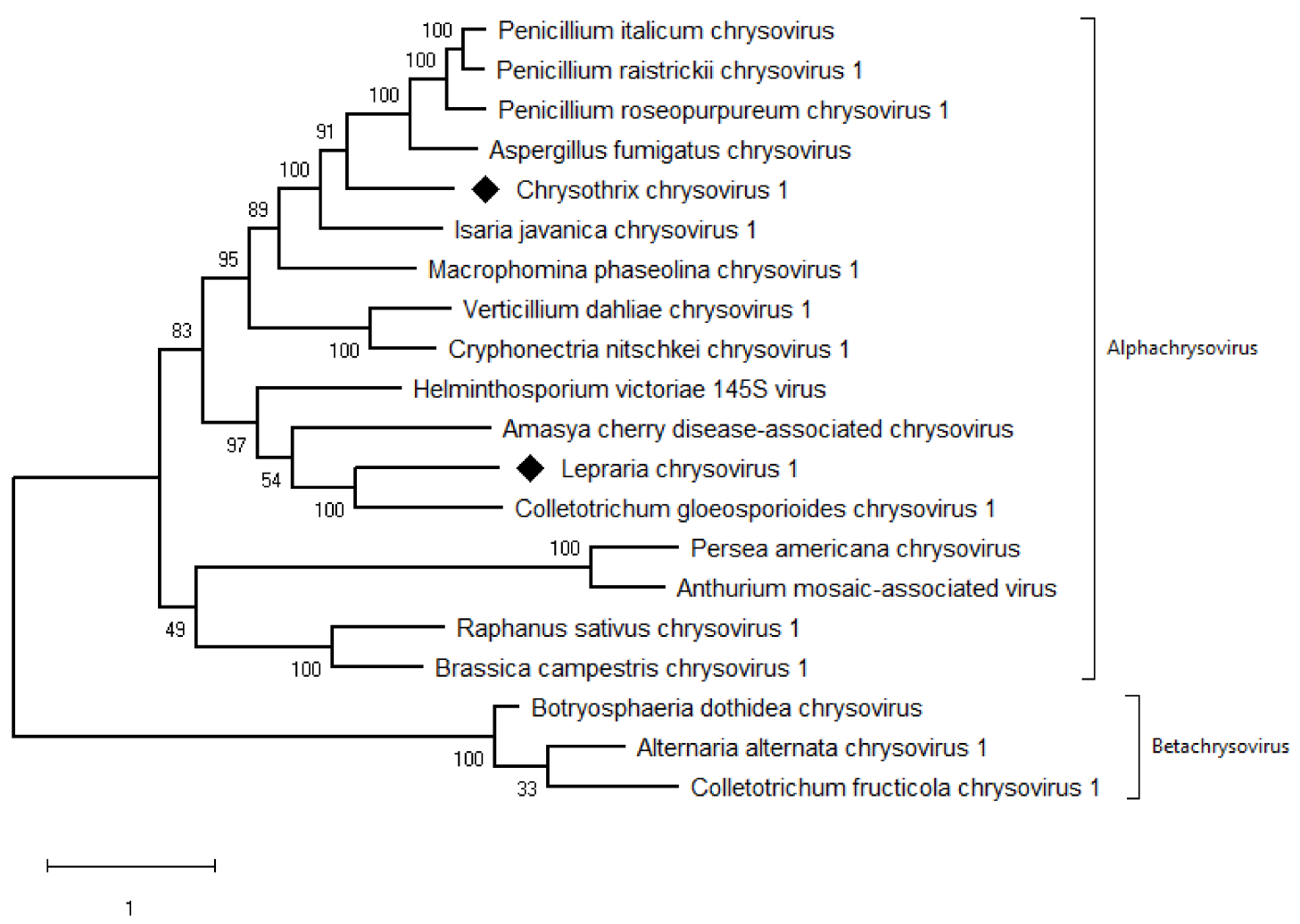

Figure 6. Phylogenetic maximum-likelihood tree computed on capsid protein amino acid sequences of alphachrysoviruses and related betachrysoviruses. The values at the nodes are bootstrap values estimated by 1000 replicates. Diamonds highlight the viruses of this work.

\subsection{Virus Localization in Lichen}

Universal fungus-specific probe and CCCV1 RNA3 segment probe were used to localize the virus inside the lichen components. In the conditions used for the hybridization $\left(46^{\circ} \mathrm{C}, 20 \%\right.$ formamide, overnight hybridization), the fungus probe penetrated hyphae and gave strong signal in the majority of hyphae (Figure 7A). The accompanying algae cells did not hybridize with the probe. This signal correlated with calcofluor white (Merck) staining of chitin. The CcCV1 RNA3 segment-specific probe Cy3-859 hybridized with material present in the cytoplasm of only a small proportion of hyphae (Figure 7B,C). These hyphae showed denser cytoplasm content and differed from the hyphae forming the lichen thallus. 

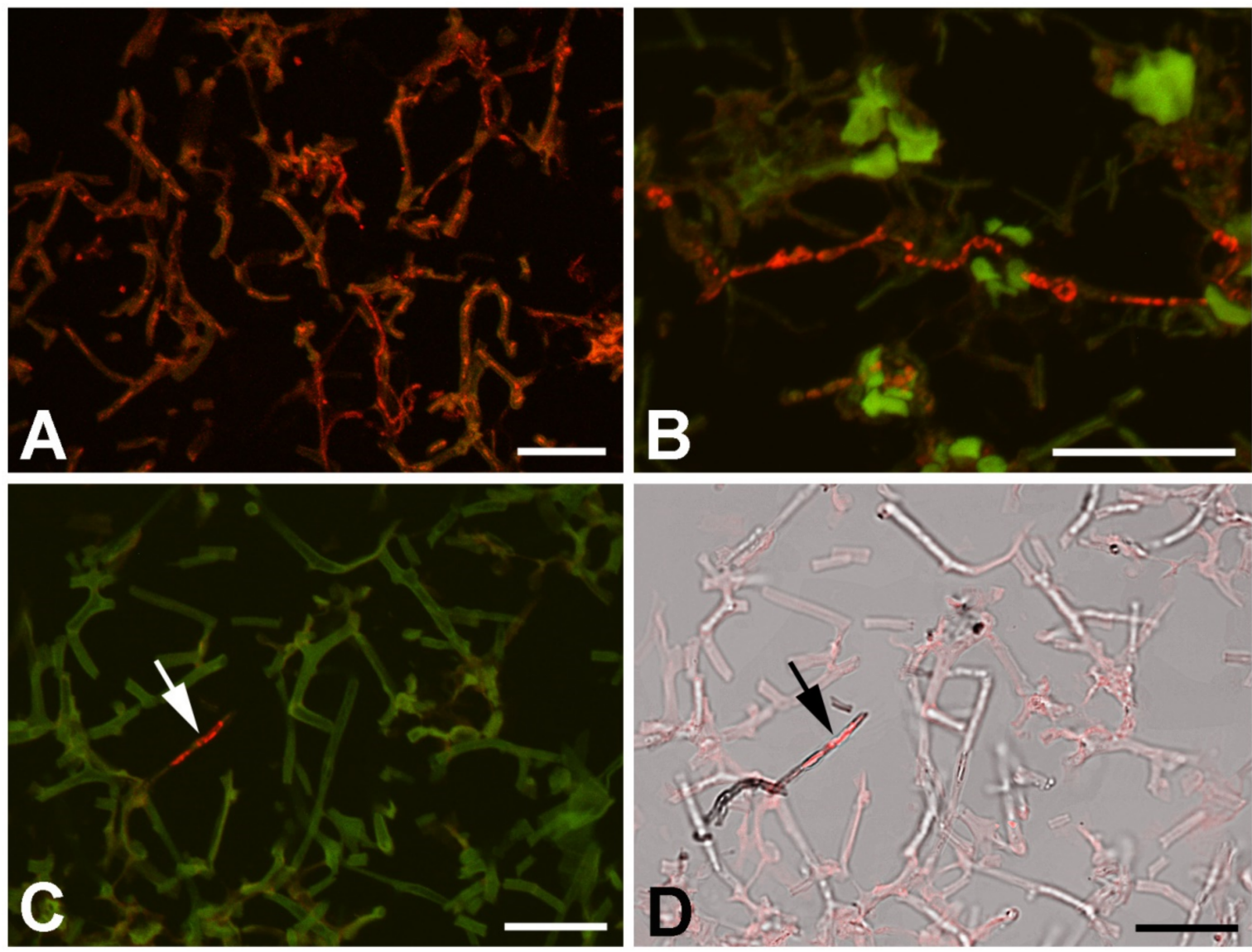

Figure 7. Confocal image of lichen thallus hybridized with fungus- and virus-specific probe. (A) Strong signal of lichen body-forming fungus with universal fungus-specific probe. (B,D) Cy3-859 hybridization signal specific for RNA3 segment of CCCV1 in distinct hyphae (in red). Positive hyphae show different color and structure (arrows). In A-C, the positive red signal is merged with an image of autofluorescence (green) excited by light of wavelength $488 \mathrm{~nm}$. In D, the positive signal (red) is merged with a bright field image. Scale $=20 \mu \mathrm{m}$.

We hypothesized that the hyphae positive for the virus presence are not hyphae of the lichen body-forming Chrysothrix but of some accompanying or endolichenic fungus. To resolve this question, we cultivated fungus-enriched fraction on PDA plates for 10 days. Newly growing fungi were picked and cultivated individually on fresh PDA plates and used for dsRNA extraction, RT-PCR virus detection, and hybridization. Penicillium citreosulfuratum from the P. citreonigrum clade [33] was identified as the host of CcCV1, inasmuch as RT-PCR with virus-specific primers gave products of expected size (Figure 8B) and the fungus reacted with the Cy3-859 probe (Figure 8D-G). The transmission of CcCV1 is uncertain. We could expect that persistence and transmission of CcCV1 would be tightly joined with the life strategy of this endolichenic fungus. In additional testing, RT-PCR screening detected CcCV1 in all single spore cultures of P. citreosulfuratum. In the hybridization experiments with the virus probe, strong signal is observed from conidiophores and from single spores of P. citreosulfuratum. That is consistent with the fact that the virus is frequently transmitted by conidia (Figure 8D-G). To highlight the lichen Chrysothrix as the complex sample, however, where the virus was first identified and where the $P$. citreosulfuratum is only a minority cohabitant, we propose the virus name be assigned according to the lichen. 


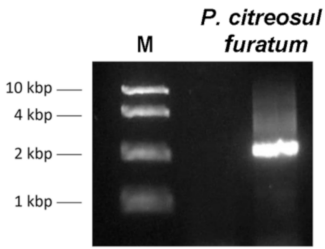

A
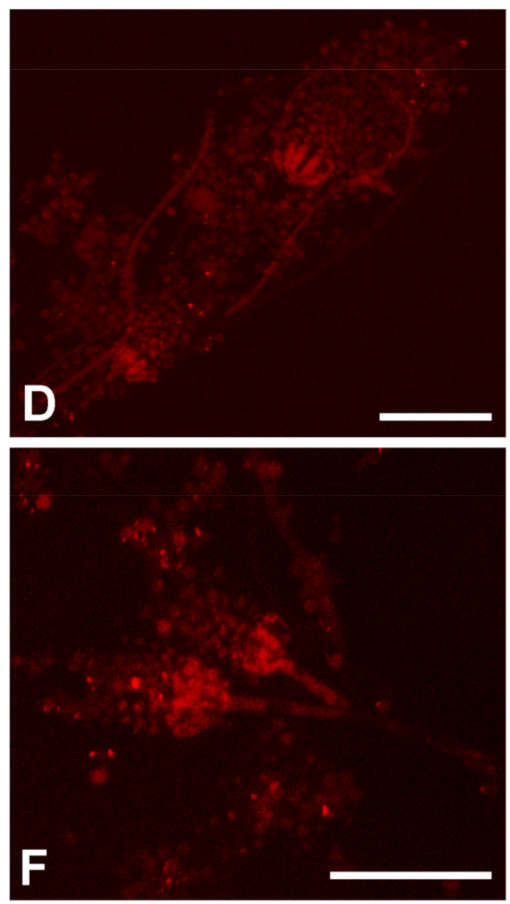

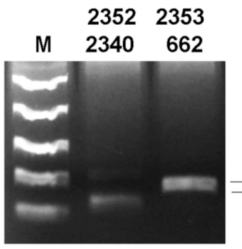

B
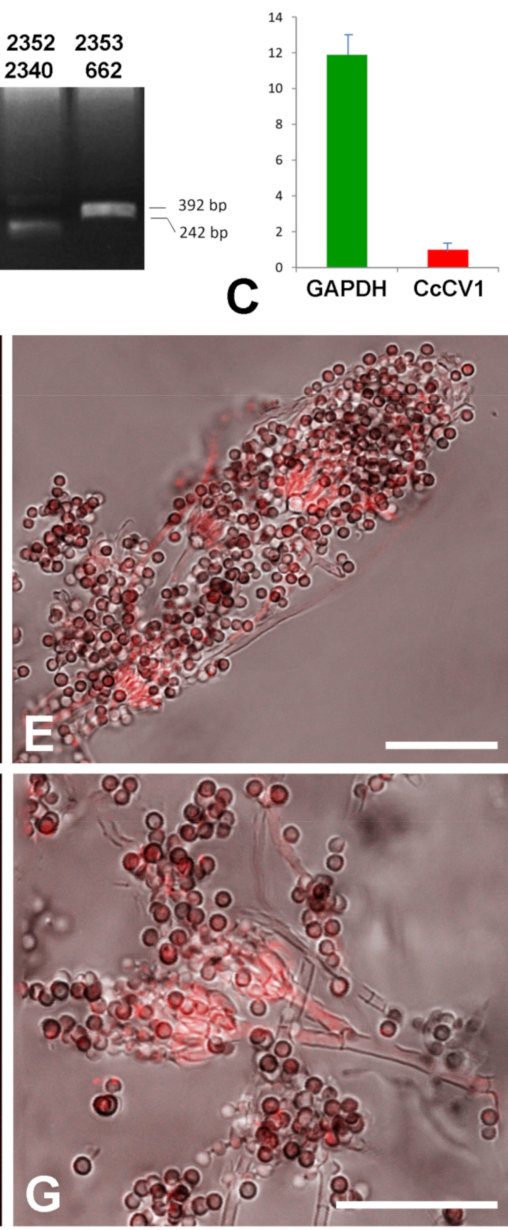

Figure 8. Characterization of $\mathrm{CcCV} 1$ in the endolichenic fungus. (A) dsRNA extracted from Penicillium citreosulfuratum endolichenic fungus, (B) PCR detection of CcCV1 with 2352 and 2340 (242 bp product), 2353 and 662 specific primers (392 bp product), (C) amount of CcCV1 relative to GAPDH housekeeping gene, (D-G) hybridization of pure culture of the endolichenic fungus with Cy3-859 probe. In (E,G) the positive signal (red) is merged with a bright field image. Scale $=20 \mu \mathrm{m}$.

\section{Discussion}

Chrysoviruses and their related viruses comprise three to five linear monocistronic dsRNA segments encapsidated separately in identical capsids 35-40 $\mathrm{nm}$ in diameter [34]. Most often, ascomycetous fungi are hosts of distinct chrysoviruses, but Agaricus bisporus virus 1 lives in a basidiomycete; RsCV1, BcCV1, Persea americana chrysovirus, ACDACV, and Anthurium mosaic-associated virus infect plants; one chrysovirus sequence was obtained from fruit fly Drosophila melanogaster [35]; and recently, Hubei chryso-like virus and Shuangao chryso-like virus were discovered in Culex mosquitos [36]. Furthermore, chrysovirus-like sequences have been identified in cDNA libraries of plant genomes, where they possibly represent the co-evolved viral lineage in plants [37]. The overall size of the genome of chrysoviruses ranges from 8.9 to $16.0 \mathrm{kbp}$. This concept of separately encapsidated dsRNA genomic monocistronic segments is probably highly effective in the evolution of mycoviruses, where viruses in the family Partitiviridae with two essential genome segments are the mycoviruses most often found (about 200 species) [38]. Viruses in the family Chrysoviridae, with 3-5 segments (25 classified species and about 20 chryso-like viruses), make up the second [39]. Mycoviruses with 4 and 11 dsRNA segments are known and classified in the family Quadriviridae and genus Mycoreovirus (one species each), respectively.

The transmission of chrysoviruses and especially CcCV1 is uncertain. Mycoviruses themselves have limited ways of transmission and, with several exceptions, they generally do not have extracellular 
routes for infection and the viral particles are not infectious. Usually they are transmitted via hyphal anastomosis and heterokaryosis or via sexual and asexual spores. In chrysoviruses, hyphal fusion experiments have demonstrated that MoCV1 is transmissible via anastomosis [40]. Transmission through ascospores observed in AthCV1 was relatively low at 37\%. The infectivity of AthCV1 particles has been documented by successful transfection of protoplasts [41]. Based on our hybridization experiments, CcCV1 is highly transmissible by conidia of P. citreosulfuratum.

The novel mycoviruses in Chrysothrix- and Lepraria-lichenized fungi are related to mycoviruses infecting filamentous fungi and could be classified as regular species of the genus Alphachrysovirus. One can only speculate thus far about the significance of these viruses in lichens, but, analogously with viruses of higher plants and fungi, we could expect an influence on lichen viability, stress tolerance, changes in morphology and/or in gene expression, and other effects. This influence could be directly on the lichen or on the accompanying endogenous fungus. In any case, the cohabitation of the Chrysothrix lichen, Penicillium citreosulfuratum endolichenic fungus and CcCV1 (Figure 9) is persistent in time, as the first samples were collected from the locality 5 years ago and CcCV1 has been detected there repeatedly up to the present. Its concentration in lichen samples as measured by extracted dsRNA varied, however, probably in relation to variable colonization by the endolichenic fungus. Concentration of CcCV1 in pure laboratory cultures of $P$. citreosulfuratum remains stable at a high concentration that is about one-tenth that of the GAPDH reference gene (Figure $8 \mathrm{C}$ ). Furthermore, the lichens could serve as reservoirs for mycoviruses as well as for herbaceous viruses, despite that the manner of transmission between different organisms is not clear [14].

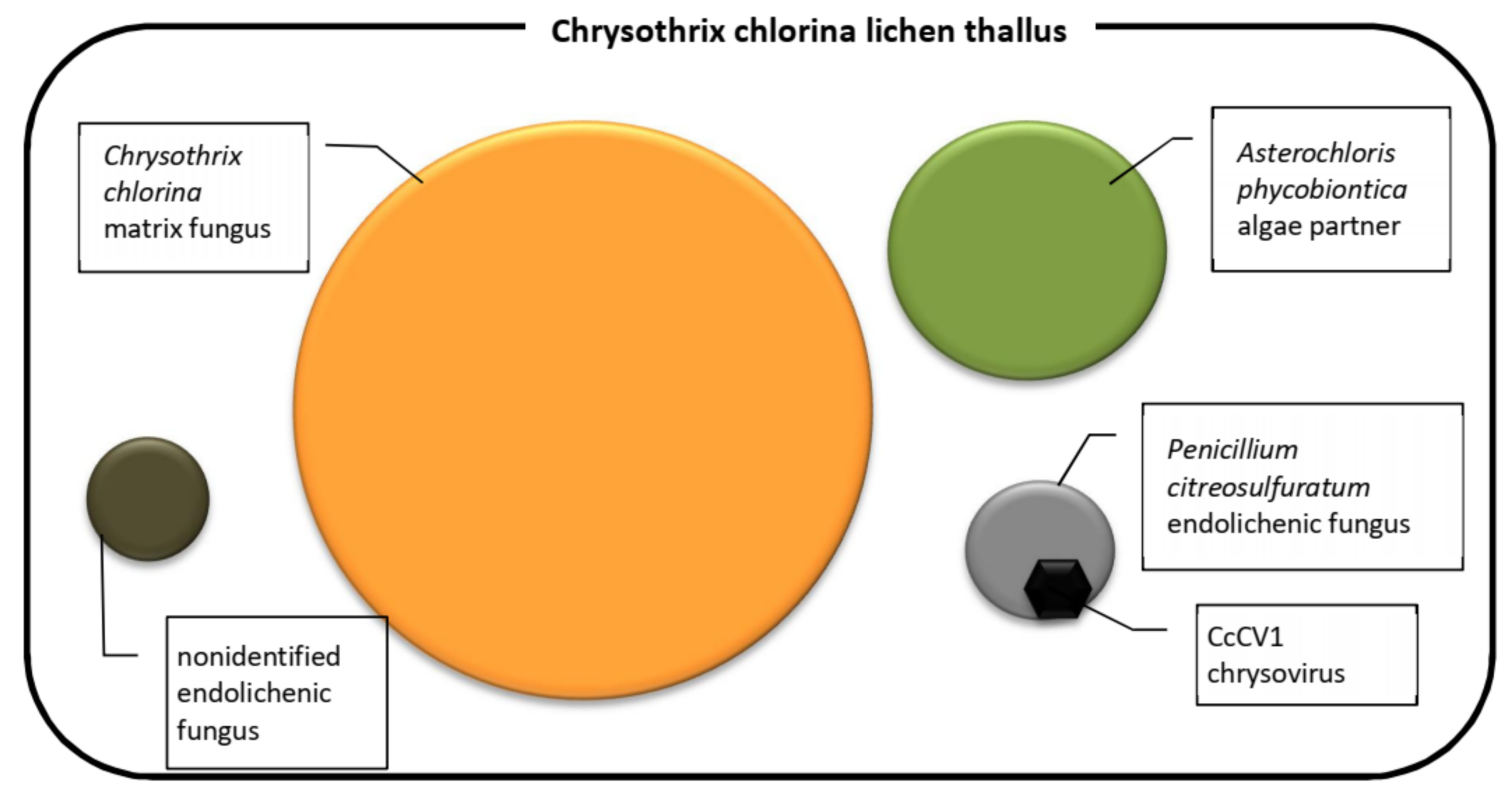

Figure 9. Components of the Chrysothrix chlorina lichen thallus.

Although most of the reported mycoviruses have been associated with cryptic or latent infections of their hosts [42], chrysoviruses relatively often have been associated with the hypovirulence phenomenon. For example, FodV1 has been associated with the induction of hypovirulence in Fusarium oxysporum f. sp. dianthi, where the virus-infected strain appeared in the intercellular spaces and with a lower colonization density in external roots [43]. Some tentative members of the family Chrysoviridae, such as Botryosphaeria dothidea chrysovirus 1 [44], Magnaporthe oryzae chrysovirus 1-A [45], Magnaporthe oryzae chrysovirus 1-B [46], and Agaricus bisporus virus 1 [47], are known to decrease virulence or cause other phenotypic changes in their fungal hosts. AaCV1 exhibits impaired growth of the host fungus and increased level of the host-specific AK-toxin [48]. The Alternaria alternata containing the AaV1 had an abnormal growth, reduced mycelial growth, aerial mycelial 
collapse, unregulated pigmentation and cytolysis, while the cured strain had a normal mycelial growth, restored pigmentation and virus content only about one-tenth as great [49]. A presence of Aspergillus thermomutatus chrysovirus 1 resulted in large ascospores production, but its host, even as the virus-free culture line, produces no ascospores. Moreover, the conidiation was 10 times greater in the virus-containing line compared to the virus-free line [41]. Cryphonectria nitschkei BS122 infected with Cryphonectria nitschkei chrysovirus 1 manifested reduced mycelial growth in comparison to the cured isogenic strain [50]. No such effects were observed in CcCV1-infected P. citreosulfuratum, however, and this cohabitation was similar to an infection by Isaria javanica chrysovirus or Raphanus sativus chrysovirus 1 in its hosts $[39,51]$.

\section{Conclusions}

A new virus distantly related to Aspergillus fumigatus chrysovirus and named Chrysothrix lichen chrysovirus 1 (CcCV1) has been found to inhabit Chrysothrix chlorina lichen. The new virus was completely sequenced and analyzed. Confocal microscopy observation of the virus hybridization signal revealed that not the lichen fungus, but an endolichenic fungus Penicillium citreosulfuratum was the main host where CcCV1 replicated. A partial genome sequence of another novel chrysovirus named Lepraria lichen chrysovirus 1 (LiCV1) was obtained from Lepraria incana lichen. Both these viruses should be classified in the genus Alphachrysovirus.

Supplementary Materials: The following are available online at http://www.mdpi.com/1999-4915/11/12/1120/s1, Table S1: Viruses, acronyms, and GenBank accession numbers of viruses used in this work, Table S2: Primers used in this study, Figure S1: Amino acid sequence identity of protein encoded on RNA3 segment, Figure S2: Amino acid sequence identity of protein encoded by RNA4 segment, Figure S3: Genome characteristics of the partially sequenced Lepraria chrysovirus 1 .

Author Contributions: K.P. conceived and designed the experiments; K.P., T.S., I.K., and H.S. performed the experiments; K.P. and I.K. analyzed the data; K.P., and H.S. wrote the paper; and K.P. revised the paper. All authors discussed the results and contributed to the final manuscript.

Funding: This work was funded by Support RVO60077344 for Biology Centre CAS, and Strategy for 21st Century CAS.

Acknowledgments: The authors thank Olga Kubešová for her excellent technical assistance.

Conflicts of Interest: The authors declare no conflict of interest. The funders had no role in the design of the study; in the collection, analyses, or interpretation of data; in the writing of the manuscript, or in the decision to publish the results.

\section{References}

1. Blair, J.E. Fungi. In The Timetree of life; Hedges, S.B., Kumar, S., Eds.; Oxford University Press: Oxford, UK, 2009; pp. 215-219.

2. Lawrey, J.D.; Diederich, P. Lichenicolous fungi: Interactions, evolution, and biodiversity. Bryol. 2003, 106, 80-120. [CrossRef]

3. Hodkinson, B.P.; Lutzoni, F. A microbiotic survey of lichen-associated bacteria reveals a new lineage from the Rhizobiales. Symbiosis 2009, 49, 163-180. [CrossRef]

4. Grube, M.; Berg, G. Microbial consortia of bacteria and fungi with focus on the lichen symbiosis. Fungal Biol. Rev. 2009, 23, 72-85. [CrossRef]

5. Kellog, J.J.; Raja, H.A. Endolichenic fungi: A new source of rich bioactive secondary metabolites on the horizon. Phytochem. Rev. 2017, 16, 271-293. [CrossRef]

6. Lawrey, J.D. Chemical interactions between two lichen-degrading fungi. J. Chem. Ecol. 2000, 26, 1821-1831. [CrossRef]

7. Lawrey, J.D.; Torzilli, A.P.; Chandhoeke, V. Destruction of lichen chemical defenses by fungal pathogen. Am. J. Bot. 1999, 86, 187-189. [CrossRef]

8. Hawksworth, D.L. The variety of fungal-algal symbioses, their evolutionary significance, and the nature of lichens. Bot. J. Linn. Soc. 1988, 96, 3-20. [CrossRef] 
9. Armstrong, R.A.; Welch, A.R. Competition in lichen communities. Symbiosis 2007, 43, 1-12.

10. Richardson, D.H.S. War in the world of lichens: Parasitism and symbiosis as exemplified by lichens and lichenicolous fungi. Mycol. Res. 1999, 103, 641-650. [CrossRef]

11. Ghabrial, S.A.; Castón, J.R.; Jiang, D.; Nibert, M.L.; Suzuki, N. 50-plus years of fungal viruses. Virology 2015, 479-480, 356-368. [CrossRef]

12. Coy, S.R.; Gann, E.R.; Pound, H.L.; Short, S.M.; Wilhelm, S.W. Viruses of eukaryotic algae: Diversity, methods for detection, and future directions. Viruses 2018, 10, 487. [CrossRef]

13. Xia, H.; Li, T.; Deng, F.; Hu, Z. Freshwater cyanophages. Virol. Sin. 2013, 28, 253-259. [CrossRef]

14. Petrzik, K.; Vondrák, J.; Barták, M.; Peksa, O.; Kubešová, O. Lichens-New source or yet unknown host of herbaceous plant viruses? Eur. J. Plant. Pathol. 2014, 138, 549-559. [CrossRef]

15. Martin, R.R.; Zhou, J.; Tzanetakis, I.E. Blueberry latent virus: An amalgam of the Partitiviridae and Totiviridae. Virus Res. 2011, 155, 175-180. [CrossRef]

16. Sabanadzovic, S.; Ghanem-Sabanadzovic, N.A. Molecular characterization and detection of a tripartite cryptic virus from rose. J. Plant. Pathol. 2008, 90, 287-293.

17. Yolken, R.H.; Jones-Brando, L.; Dunigan, D.D.; Kannan, G.; Dickerson, F.; Severance, E.; Sabunciyan, S.; Talbot, C.C.; Prandovszky, E.; Gurnon, J.R.; et al. Chlorovirus ATCV-1 is part of the human oropharyngeal virome and is associated with changes in cognitive functions in humans and mice. Proc. Nat. Acad. Sci. USA 2014, 111, 16106-16111. [CrossRef]

18. Ekman, S.; Tønsberg, T. Most species of Lepraria and Leproloma form a monophyletic group closely related to Stereocaulon. Mycol. Res. 2002, 106, 1262-1276. [CrossRef]

19. Antane, S.; Caufield, C.E.; Hu, W.; Keeney, D.; Labthavikul, P.; Morris, K.; Naughton, S.M.; Petersen, P.J.; Rasmussen, B.A.; Singh, G.; et al. Pulvinones as bacterial cell wall biosynthesis inhibitors. Bioorg. Med. Chem. Lett. 2006, 16, 176-180. [CrossRef]

20. Sahin, E.; Psav, S.D.; Avan, I.; Candan, M.; Sahinturk, V.; Koparal, A.T. Vulpinic acid, a lichen metabolite emerges as a potential drug candidate in the therapy of oxidative stress-related diseases, such as atherosclerosis. Human Exp. Toxicol. 2019, 38, 675-684. [CrossRef] [PubMed]

21. Saag, L.; Saag, A.; Randlane, T. World survey of the genus Lepraria (Stereocaulaceae, lichenized Ascomycota). Lichenol. 2009, 41, 25-60. [CrossRef]

22. Lubicz, J.V.; Rush, C.M.; Payton, M.; Colberg, T. Beet necrotic yellow vein virus accumulates inside resting spores and zoosporangia of its vector Polymyxa betae BNYVV infects P. betae. Virol. J. 2007, 4, 37. [CrossRef] [PubMed]

23. Morris, T.J.; Dodds, J.A. Isolation and analysis of double-stranded RNA from virus-infected plant and fungal tissue. Phytopathology 1979, 69, 854-858. [CrossRef]

24. Darissa, O.; Willingmann, P.; Adam, G. Optimized approaches for the sequence determination of double-stranded RNA templates. J. Virol. Methods 2010, 169, 397-403. [CrossRef] [PubMed]

25. White, T.J.; Bruns, T.; Lee, S.; Taylor, J. Amplification and direct sequencing of fungal ribosomal RNA genes for phylogenetics. In PCR Protocols: A Guide to Methods and Applications; Innis, M.A., Gelfand, D.H., Sninsky, J.J., White, T.J., Eds.; Academic Press: San Diego, CA, USA, 1990; pp. 315-322.

26. Gasulla, F.; Guéra, A.; Barreno, E. A simple and rapid method for isolating lichen photobionts. Symbiosis 2010, 51, 175-179. [CrossRef]

27. Thompson, J.D.; Gibson, T.J.; Plewniak, F.; Jeanmougin, F.; Higgins, D.G. The CLUSTAL X windows interface: Flexible strategies for multiple sequence alignment aided by quality analysis tools. Nucleic Acids Res. 1997, 25, 4876-4882. [CrossRef]

28. Kumar, S.; Stecher, G.; Tamura, K. Molecular Evolutionary Genetics Analysis version 7.0 for bigger datasets. Mol. Biol. Evol. 2016, 33, 1870-1874. [CrossRef]

29. Gao, J.X.; Chen, J. Transcriptome analysis identifies candidate genes associated with melanin and toxin biosynthesis and pathogenicity of the maize pathogen, Curvularia lunata. J. Phytopathol. 2018, 166, $233-241$. [CrossRef]

30. Baschien, C.; Manz, W.; Neu, T.R.; Marvanová, L.; Szewzyk, U. In situ detection of freshwater fungi in an alpine stream by new taxon-specific fluorescence in situ hybridization probes. Appl. Environ. Microb. 2008, 74, 6427-6436. [CrossRef] 
31. Zimmermann, L.; Stephens, A.; Nam, S.Z.; Rau, D.; Kübler, J.; Lozajic, M.; Gabler, F.; Söding, J.; Lupas, A.N.; Alva, V. A completely reimplemented MPI Bioinformatics Toolkit with a new HHpred server at its core. J. Mol. Biol. 2018, 430, 2237-2243. [CrossRef]

32. ICTV Taxonomy history: Alphachrysovirus, 2018b. Available online: https:/talk.ictvonline.org//taxonomy/ p/taxonomy-history?taxnode_id=201852890 (accessed on 4 November 2019).

33. Visagie, C.M.; Seifert, K.A.; Houbraken, J.; Samson, R.A.; Jacobs, K. A phylogenetic revision of Penicillium sect. Exilicaulis, including nine new species from fynbos in South Africa. IMA Fungus 2016, 7, 75-117. [CrossRef]

34. Ghabrial, S.A.; Castón, J.R. Chrysoviridae. In Virus Taxonomy: Ninth Report of the International Committee on Taxonomy of Viruses; King, A.M.Q., Adams, M.J., Carstens, E.B., Lefkowitz, E.J., Eds.; Elsevier: Amsterdam, The Netherlands, 2012; pp. 509-513.

35. Webster, C.L.; Waldron, F.M.; Robertson, S.; Crowson, D.; Ferrari, G.; Quintana, J.F.; Brouqui, J.M.; Bayne, E.H.; Longdon, B.; Buck, A.H.; et al. The discovery, distribution, and evolution of viruses associated with Drosophila melanogaster. PLoS Biol. 2015, 13, e1002210. [CrossRef]

36. Shi, M.; Neville, P.; Nicholson, J.; Eden, J.S.; Imrie, A.; Holmes, E.C. High-Resolution metatranscriptomics reveals the ecological dynamics of mosquito-associated RNA viruses in Western Australia. J. Virol. 2017, 92, e00680-17. [CrossRef] [PubMed]

37. Liu, H.; Fu, Y.; Xie, J.; Cheng, J.; Ghabrial, S.A.; Li, G.; Yi, X.; Jiang, D. Discovery of novel dsRNA viral sequences by in silico cloning and implications for viral diversity, host range and evolution. PLOS ONE 2012, 7, e42147. [CrossRef] [PubMed]

38. Petrzik, K. Evolutionary forces at work in partitiviruses. Virus Genes 2019, 55, 563-573. [CrossRef]

39. Li, L.; Liu, J.; Xu, A.; Wang, T.; Chen, J.; Zhu, X. Molecular characterization of a trisegmented chrysovirus isolated from the radish Raphanus sativus. Virus Res. 2016, 176, 169-178. [CrossRef] [PubMed]

40. Higashiura, T.; Katoh, Y.; Urayama, S.; Hayashi, O.; Aihara, M.; Fukuhara, T.; Fuji, S.; Kobayashi, T.; Hase, S.; Arie, T.; et al. Magnaporthe oryzae chrysovirus 1 strain D confers growth inhibition to the host fungus and exhibit multiform viral structural proteins. Virology 2019, 535, 241-254. [CrossRef]

41. Ejmal, M.A.; Holland, D.J.; MacDiarmid, R.M.; Pearson, M.N. A novel chrysovirus from a clinical isolate of Aspergillus thermomutatus affects sporulation. PLoS ONE 2018, 13, e0209443. [CrossRef]

42. Ghabrial, S.A.; Suzuki, N. Viruses of plant pathogenic fungi. Annu. Rev. Phytopathol. 2009, 47, 353-384. [CrossRef]

43. Torres-Trenas, A.; Prieto, P.; Cañizares, M.C.; García-Pedrajas, M.D.; Pérez-Artés, E. Mycovirus Fusarium oxysporum f. sp. dianthi virus 1 decreases the colonizing efficiency of its fungal host. Front. Cell. Infect. Mi. 2019, 9, 51. [CrossRef]

44. Wang, L.; Jiang, J.; Wang, Y.; Hong, N.; Zhang, F.; Xu, W.; Wang, G. Hypovirulence of the phytopathogenic fungus Botryosphaeria dothidea: Association with a coinfecting chrysovirus and a partitivirus. J. Virol. 2014, 88, 7517-7527. [CrossRef]

45. Urayama, S.; Kato, S.; Suzuki, Y.; Aoki, N.; Le, M.T.; Arie, T.; Teraoka, T.; Fukuhara, T.; Moriyama, H. Mycoviruses related to chrysovirus affect vegetative growth in the rice blast fungus Magnaporthe oryzae. J. Gen. Virol. 2010, 91, 3085-3094. [CrossRef] [PubMed]

46. Urayama, S.; Sakoda, H.; Takai, R.; Katoh, Y.; Minh, L.T.; Fukuhara, T.; Arie, T.; Teraoka, T.; Moriyama, H. A dsRNA mycovirus, Magnaporthe oryzae chrysovirus 1-B, suppresses vegetative growth and development of the rice blast fungus. Virology 2014, 448, 265-273. [CrossRef] [PubMed]

47. Harmsen, M.C.; Tolner, B.; Kram, A.; Go, S.J.; de Haan, A.; Wessels, J.G.H. Sequences of three dsRNAs associated with La France disease of the cultivated mushroom (Agaricus bisporus). Curr. Genet. 1991, 20, 137-144. [CrossRef] [PubMed]

48. Moriyama, H.; Urayama, S.; Higashiura, T.; Le, T.M.; Komatsu, K. Chrysoviruses in Magnaporthe oryzae. Viruses 2018, 10, 697. [CrossRef]

49. Aoki, N.; Moriyama, H.; Kodama, M.; Arie, T.; Teraoka, T.; Fukuhara, T. A novel mycovirus associated with four double-stranded RNAs affects host fungal growth in Alternaria alternata. Virus Res. 2009, 140, 179-187. [CrossRef] 
50. Kim, J.M.; Jung, J.E.; Park, J.A.; Park, S.M.; Cha, B.J.; Kim, D.H. Biological function of a novel chrysovirus CnV1-BS122, in the Korean Cryphonectria nitschkei BS122 strain. J. Biosci. Bioeng. 2012, 115, 1-3. [CrossRef]

51. Herrero, N. Identification and sequence determination of a new chrysovirus infecting the entomopathogenic fungus Isaria javanica. Arch. Virol. 2017, 162, 1113-1117. [CrossRef]

(C) 2019 by the authors. Licensee MDPI, Basel, Switzerland. This article is an open access article distributed under the terms and conditions of the Creative Commons Attribution (CC BY) license (http://creativecommons.org/licenses/by/4.0/). 